\title{
EVANGELICALS AND THE EVANGEL
}

\author{
Michael Horton \\ Westminster Seminary California \\ Korespondensi: mshorton@wscal.edu
}

\begin{abstract}
In this article, the author argues on the importance of the Reformation. Despite over 500 years has passed since the reformation, the roman catholic church has not moved towards the true understanding of the gospel, in terms of justification as being declared right. Furthermore, in the author's context of American Evangelism, pelagianism seems taking over the mindset of the biblically illiterate. The preaching of the evangel that justifies the ungodly must be the call of the day.
\end{abstract}

KEYWORDS: evangel; justification; roman catholic; pelagian.

ABSTRAK: Dalam artikel ini, penulis menunjukkan pentingnya Reformasi. Sekalipun lebih dari 500 tahun berlalu sejak reformasi, gereja Roma Katolik masih belum mendekat kepada pengertian injil mengenai pembenaran sebagai dinyatakan benar. Lebih lagi, di dalam konteks penulis akan kaum injili di amerika, pelagianisme sepertinya telah mengambil alih pemikiran orang-orang yang tidak dapat membedakan mana ajaran alkitab dan yang bukan. Pemberitaan injil yang membenarkan orang fasik merupakan panggilan mendesak saat ini.

KATA KUNCI: injil; pembenaran; roma katolik; pelagian.

Invited to give a plenary address in Wittenberg on the weekend of the Reformation's quincentenary, I took my teenage son on a tour of Luther sites along the way. I'll use this travelogue as a way of exploring what it means - or at least meant-to be an "evangelical."

We visited the cell of the Erfurt monastery in which the Augustinian monk searched passionately and, for the most part, in vain, for a gracious God.

"Just love God," his confessor counseled, but Martin was not just an overly scrupulous monk. He was not even looking first of all for a gracious 
God but the real God, whoever he might be. ${ }^{1}$ But the more he read the Bible, the further he felt from this God. It was not the mercy, love and grace of God that struck him at first but God's righteousness, holiness and justice.

As a theology student, Luther had been taught that "God will not deny his grace to those who do what lies within them." Following Scotus and Ockham, his teachers thought they were making salvation more accessible. Just take even the smallest step and God will accept it. Contrition (sorrow for sin) isn't necessary, just attrition (fear of judgment). The sacrament of penance isn't required, as long as your love God above all else in your heart. "Love God? I hate him!" That was where such teaching drove Luther. After all, "Love God with all your heart, soul, mind and strength and your neighbor as yourself" was Jesus' summary of the law.

Happily, there was Johann von Staupitz, head of the Augustinian Order for all of Germany and Luther's mentor. "If it had not been for Dr. Staupitz, I should have sunk in hell," Luther recalled. ${ }^{2}$ True to the Order's namesake, Staupitz directed the anxious monk to the wounds of Christ outside of him, to God's grace in election, forgiveness and preservation of his people. It was a stroke of genius when Staupitz sent Luther in 1508 to teach the Bible at the newly established University. As he lectured on the Psalms, Romans and Galatians, he was as much the student as the professor. It pained Luther later when his aged teacher refused openly to join the Reformation.

We mark October 31, 1517, as the beginning of the Reformation, but the "Ninety-Five Theses" say nothing about the justification of the ungodly. What Luther finds scandalous about the traffic in indulgences is its misrepresentation of God as a banker who can be bought off, literally. More than that, he is remote, outsourcing the management of the "treasury of merits" to a church that had unlimited power to set the terms for human destiny beyond the grave. Beginning with the first of his famous theses, Luther protested that the sale of indulgences threatened repentance, with no mention of justification. You could buy-down your purgatorial sentence in the morning and stop by the whorehouse at night.

It was in 1520 when Luther, through the assistance of Philip Melanchthon, came to understand clearly that God justifies the wicked by Christ's "alien righteousness."3 The only person who fulfilled the law completely, from the heart, was the incarnate Son, Jesus Christ. For the

\footnotetext{
This point is developed richly by Scott Hendrix in Martin Luther: Visionary Reformer (New Haven: Yale University Press, 2015).

2 Quoted in Roland Bainton, Here I Stand: A Life of Martin Luther (Nashville: Abingdon Press, 1950), 53.

3 On Melanchthon's role in this story see R. S. Clark, "Iustitia Imputata Christi: Alien or Proper to Luther's Doctrine of Justification?", Concordia Theological Quarterly 70:3/4 (July/Oct 2006), 269-310.
} 
early Luther, the example of Jesus - his complete surrender to God's righteousness - was just more "law." The righteousness of God condemns. It offers no relief to transgressors, no bending of the rules, no time off for good behavior. "Now we know that whatever the law says it speaks to those who are under the law, so that every mouth may be stopped, and the whole world may be held accountable to God. For by works of the law no human being will be justified in his sight, since through the law comes knowledge of $\sin ^{\prime \prime}$ (Rom 3:19-20).

It was not that his teachers and the pope's traveling salesmen like Tetzel were too legalistic but that they were antinomian - setting aside God's law for their vain and indeed villainous propitiations. They did not take God seriously. They kept changing the rules of the game in order to manage both God and the masses, imagining that they were making the path to justification easier.

Luther, however, took the righteousness of God revealed in the law with utter seriousness. The righteousness of God condemns everyone without exception because "no one is righteous, no not one" (Romans 1:18-3:20). Then he discovered Paul's shift from the law to the gospel, from the righteousness of God to the righteousness from God in verses 21 to 31:

But now the righteousness of God has been manifested apart from the law, although the Law and the Prophets bear witness to it-the righteousness of God through faith in Jesus Christ for all who believe. For there is no distinction: for all have sinned and fall short of the glory of God, and are justified by his grace as a gift, through the redemption that is in Christ Jesus, whom God put forward as a propitiation by his blood, to be received by faith. This was to show God's righteousness, because in his divine forbearance he had passed over former sins. It was to show his righteousness at the present time, so that he might be just and the justifier of the one who has faith in Jesus.

Then what becomes of our boasting? It is excluded. By what kind of law? By a law of works? No, but by the law of faith. For we hold that one is justified by faith apart from works of the law. Or is God the God of Jews only? Is he not the God of Gentiles also? Yes, of Gentiles also, since God is one-who will justify the circumcised by faith and the uncircumcised through faith. Do we then overthrow the law by this faith? By no means! On the contrary, we uphold the law (Rom 3:21-31).

Sinners are declared righteous not because of some "legal fiction" but by the imputation (crediting) of Christ's fulfillment of the law to all who are united to him through faith alone. This justification is a gift bestowed, not a goal to be achieved. 
Our next stop on the Luther trail was the Wartburg Castle, where a superb exhibit of the Reformation had attracted scores of tour buses.

Having presided over the Diet of Worms, the emperor decreed that the now-excommunicated reformer was to be regarded as a heretic and hunted down as an outlaw. On his way back to Wittenberg from Worms, Luther was "abducted" cleverly by the Elector of Saxony, Frederick III. Through 1521 the Wartburg was what Luther called "my Patmos," where he translated the New Testament into German. In his absence, though, Wittenberg had taken a radical turn. Karlstadt, his associate from the beginning, had come to reject the baptism of infants and encouraged popular insurrection against the secular authorities.

Luther had encountered the offered a worldly kingdom before. Ulrich von Hutten, leader of the Knights of the German Empire, intercepted Luther to offer the services of the knights. Fiercely anti-Rome even before Luther arrived on the scene, his main inspiration was German nationalism. Lamenting that men still want to take the kingdom by force, Luther rejected the offer in no uncertain terms.

But now Wittenberg itself was set on fire by violent spirits. Ransacking churches, Karlstadt appealed to the holy wars of the Old Testament and his own inspiration by the Spirit. For Luther and other reformers, "enthusiasm" - literally, "God-within-ism," is the nadir of idolatry. Locating authority within, as if the deepest self were a spark of divinity, renders the individual the source of the law and the gospel. "Adam was the first enthusiast," Luther said, turning away from the external Word of God that judges and justifies. ${ }^{4}$ Wittenberg became a seedbed of radical Anabaptist sects, such as the Zwickau prophets, who claimed the imminent return of Christ to institute a millennial reign. It would be nothing less than a restoration of the golden age of the church in the Book of Acts.

Instead, Luther returned after pleas from the city council and the reformer set about immediately to restore order not through force but through the preaching of the Word.

I will preach, but I will force no one; for faith must be voluntary. Take me as an example. I stood up against the Pope, indulgences, and all papists, but without violence or uproar. I only urged, preached, and declared God's Word, nothing else. And yet while I was slumbering or drinking Wittenberg beer with Philip Melanchthon and Amsdorf, the Word inflicted more serious damage on popery than prince or emperor. I did nothing, the Word did everything...Do you know what the Devil thinks when he sees men use 
violence to propagate the gospel? He sits with folded arms behind the fire of hell, and says with malignant looks and frightful grin: 'Ah, how wise these madmen are to play my game! Let them go on; I shall reap the benefit. I delight in it.' But when he sees the Word running and contending alone on the battlefield, then he shudders and shakes for fear. The Word is almighty, and takes captive all hearts. ${ }^{5}$

The radicals were not interested in Luther's evangelical message, but in establishing a Spirit-led commonwealth where the millennial reign of Christ replaces both church and state. In fact, no less than the pope were the Anabaptists opposed to justification by grace alone through faith alone by Christ's merits alone as a false gospel that undermined the very activism that was necessary to build his kingdom on earth.

The "Enthusiasts" were expelled and Luther wrote sharply-worded treatises against the "Fanatics" like his former student, Thomas Müntzer, who "thinks he swallowed the Holy Spirit, feathers and all!" Radical Anabaptists contrasted the clergy - preachers of the "outer Word that beats the air" and administrators of the "outer sacraments" - with their radical version of the priesthood of all believers. Announcing the dawn of the "Age of the Spirit," they thought that every true believer receives visions and prophecies directly from God. Müntzer fomented numerous uprisings, taking cities and towns by violence. Radicals took Münster in 1534, slaughtering many of its inhabitants, especially clergy, and instituted a violent, communistic and polygamous state ruled by John of Leiden who called himself "King David."

The Reformation therefore was not only opposed by the Roman church but by radical protestants. Paul's contrast of "the letter" and "the Spirit" (1 Cor 3) referred to the old and new covenants. Anabaptists, however, read it in a Gnostic manner, as a division between everything external, physical and mediated by human ministry and everything internal, spiritual and immediate. This extended even to their view of Christ, rejecting his complete humanity. The "outer" ministry of the Word and sacraments was being superseded by the "inner" ministry of the Holy Spirit through direct revelations, visions and prophecies. Luther said,

This is what Müntzer did and what is done today by very many people who want to be judges discerning between the spirit and the letter, and who do not know what they are saying or teaching. Papism is also pure enthusiasm, since the Pope claims to 'keep all laws in the casket of his heart' and since everything that he decides and commands with his Church is spirit 
and must be regarded as just, even if it goes beyond Scripture or the spoken word and is contrary to them...That is why we have the right and we are obliged to insist that God is only able to enter into a relationship with us men through the external word and the sacraments. Everything that is said of the Spirit independently of this word and the sacraments is the devil! ${ }^{6}$

Similarly, John Calvin told Cardinal Sadoleto, "We are assailed by two sects: the Pope and the Anabaptists." Both claim an ongoing apostolic office, boasting in continuing revelations. "In this way, both separate the Word from the Spirit and bury the Word of God in order to make room for their falsehood." ${ }^{7}$

The greatest of these falsehoods was the anathematizing of the gospel itself by a reliable group selected carefully by the pope. Meeting in 1546, the sixth session of the Council of Trent decreed:

CANON IX.-If any one says that by faith alone the impious is justified...let him be anathema.

CANON XI.-If any one says that men are justified, either by the sole imputation of the justice of Christ, or by the sole remission of sins...let him be anathema.

CANON XII.-If any one says that justifying faith is nothing else but confidence in the divine mercy which remits sins for Christ's sake; or, that this confidence alone is that whereby we are justified; let him be anathema.

CANON XV.-If any one says that a man, who is born again and justified, is bound of faith to believe that he is assuredly in the number of the predestinate; let him be anathema.

CANON XVI.-If any one says that he will for certain, of an absolute and infallible certainty, have that great gift of perseverance unto the end,-unless he have learned this by special revelation; let him be anathema.

CANON XXIV.-If any one says that the justice received is not preserved and also increased before God through good works; but that the said works are merely the fruits and signs of Justification obtained, but not a cause of the increase thereof; let him be anathema.

CANON XXX.-If any one says that, after the grace of Justification has been received, to every penitent sinner the guilt is remitted, and the debt of eternal punishment is blotted out in such wise, that there remains not any debt of temporal punishment to be discharged either in this world, or in the next in Purgatory, before the entrance to the kingdom of heaven can be opened (to him); let him be anathema.

\footnotetext{
6 Luther, "Smalcald Articles," in Triglot Concordia: The Symbolical Books of the Evangelical Lutheran Church (St. Louis: Concordia, 1921), 3.8.

7 Calvin, "Reply by John Calvin to Cardinal Sadoleto's Letter," in Selected Works of John Calvin: Tracts and Letters, ed. Henry Beveridge and Jules Bonnet, 7 vols. (Grand Rapids: Baker, 1983), 1:36.
} 
CANON XXXII.-If any one says that the good works of one that is justified are in such manner the gifts of God, as that they are not also the good merits of him that is justified; or, that the said justified...does not truly merit increase of grace, eternal life, and the attainment of that eternal life,-if so be, however, that he depart in grace,-and also an increase of glory; let him be anathema.

"Lutheran" was a sectarian label coined by papal opponents, but Luther insisted on the moniker "evangelical," from the noun euangelion (gospel, "good news"). It was the recovery of the gospel that distinguished this cause from the works-righteousness and mystical "enthusiasm" of the pope on one side and the Anabaptists on the other.

Finally, we drove into Wittenberg with a bronze Luther preaching in the center of the city square, facing the Castle Church.

Packed with tourists, the plaza resembled a Renaissance fair with all sorts of food, drink, trinkets and costumed musicians. Banners festooned the broad alleys proclaiming the five-hundredth anniversary of the Reformation. Reporters staked their claim throughout the square where Angela Merkel would address the nation from the Castle Church, construing the Reformation as an appeal for religious tolerance.

A year previously, Pope Francis and the head of the World Lutheran Federation anticipated the occasion in a joint service. Steering clear of doctrine (and the excommunication of Luther still in place), the pope honored Luther's stand against greed and corruption. Another celebration followed in Berlin, with the Swiss Reformed representative asserting, "Reformation means courageously seeking what is new and turning away from old, familiar customs." 8 And now, in Wittenberg on Reformation Day, I discerned no sign of the actual message that changed the world...until we joined a modest gathering of believers inside a hotel ballroom.

In contrast with the mainline World Communion of Reformed Churches, the World Reformed Fellowship consists of church bodies committed to the inerrant scriptures and to the creeds and confessions as subordinate standards. There were no reporters or dramatic historical re-enactments. Though slight in comparison with all the activity outside, representative leaders had been sent by their churches from places that the reformers had never heard of. Three Anglican archbishops attended, representing more than the total of communicant members in the Church of England.

The largest confessional Reformed denomination in the United States is the Presbyterian Church in America (PCA), with 384,000 members. Yet

\footnotetext{
Stephen Brown, "Reformation celebrations will be ecumenical and international, says German Protestant leader," https://www.oikoumene.org/en/press-centre/news/reformation-celebrations-will-be-ecumenical-and-international-says-german-protestant-leader, retrieved 2 July, 2016.
} 
sister churches abroad include the Presbyterian Church of Brazil $(650,000)$, the Evangelical Reformed Churches of Christ in Nigeria (6 million) and in South Korea, Reformed and Presbyterian believers number around 10 million. Though located in the capitol of the world's most populous Muslim nation, the Evangelical Reformed Church in Indonesia has reached millions throughout the region with the gospel.

Analogous figures could be given for confessional Lutherans: for example, 100,000 in Kenya and the same number in Papua New Guinea. And even mainline denominations in the majority world are more orthodox today than the European, British and American churches spearheaded the modern missionary movement. Taking its stand on the authority of Scripture, salvation through Christ alone, and the teachings of the Thirty-Nine Articles, the Global Anglican Future Conference (CAFCON) represents about 35 million regular church-attenders, mostly in the Global South, while 800,000 attend church on an average Sunday in the Church of England - the great majority of these attending evangelical parishes.

As we looked around at each other's faces, singing "A Mighty Fortress Is Our God," it was difficult to hold back tears of joy, even as we wept for the land of the Reformation and the declining light of the gospel across Europe and North America.

\section{Evangelicals and the Evangel Today}

I learned during the 1990s how easily respected evangelical leaders could surrender the doctrine of justification. The project known as "Evangelicals and Catholics Together" claimed agreement on the gospel regardless of differences over justification. In the face of growing secularism, it was thought, Roman Catholics and evangelicals need to stand together. To be sure, I argued, wherever we can - on the Trinity, the dignity of all people created in God's image, original sin, the need for Christ's atonement, the return of Christ and the resurrection of the dead. But to affirm that we agree on the gospel entails that justification solely by Christ's imputed merits is not essential to the good news. Defending his signature of ECT, a good friend, mentor and justly esteemed Reformed stalwart even called the imputation of Christ's righteousness "the fine print."

According to the current Catholic Catechism, "'justification is not only the remission of sins, but also the sanctification and renewal of the interior man."'"9 Justification is therefore regarded as a process of becoming actually

The Catechism of the Catholic Church (New York: USCCB, 1995), 492, quoting the Council of Trent (1574): DS 1528 
and intrinsically righteous. The first justification occurs at baptism, which eradicates both the guilt and corruption of original $\sin .{ }^{10}$ Due entirely to God's grace, this initial justification infuses the habit (or principle) of grace into the recipient. By cooperating with this inherent grace, one merits an increase of grace and, one hopes, final justification. ${ }^{11}$ So while initial justification is by grace alone, persevering and final justification depends also on the works of the believer, which God graciously accepts as meritorious. ${ }^{12}$ Since the believer's progress in holiness is never adequate to cancel the guilt of actual sins, he or she must be refined in purgatory before being welcomed into heaven. ${ }^{13}$

The Reformers did not divide the church. On the contrary, the four popes who presided over the Counter-Reformation recklessly and for their own personal gain rent the fabric of Christ's church, pretending that the rotten piece was the pure garment of Christ's bride. And even in the last century of ecumenical dialogue, Rome has never had to move an inch from its material positions. The movement toward doctrinal change has been entirely on the Protestant side.

Most recently, the Joint Declaration on the Doctrine of Justification (1999) including representatives of the Vatican and the Lutheran World Federation, achieved a consensus sufficient to justify the announcement that the condemnations of the sixteenth century no longer apply to the partner in dialogue. ${ }^{14}$ Subsequently, the other mainline bodies-Reformed, Anglican, Methodist and Baptist-joined their Lutheran counterpart in announcing reconciliation on the Reformation's chief point of division.

In my view, the Joint Declaration did not achieve the results for which many hoped and, as Eberhard Jüngel judges, "the understanding that allegedly has been reached rests on ground which proves at places quite slippery." 15 On the Lutheran side, the confessional doctrine of justification was surrendered at crucial points, particularly the conflation of faith and love and therefore justification and sanctification. ${ }^{16}$ On the Roman Catholic

10 The Catechism of the Catholic Church, 482

The Catechism of the Catholic Church, 483

The Catechism of the Catholic Church, 486-487

The Catechism of the Catholic Church, 268.

14 Lutheran World Federation and the Roman Catholic Church, Joint Declaration on the Doctrine of Justification (Grand Rapids: Eerdmans, 2000), 10-11.

15 Eberhard Jüngel, Justification: The Heart of the Christian Faith, trans. Jeffrey F. Cayzer; $2^{\text {nd }}$ ed. (London: Bloomsbury T\&T Clark, 2014), xxxix. The chief critic of the Joint Delcaration when it appeared, Jüngel (who has also been long engaged in ecumenical discussions) wrote this entire book as a way of clarifying the Lutheran doctrine.

16 Joint Declaration, 18, with the section titled "Justification as Forgiveness of Sins and Making Righteous" (my emphasis). In the act of justification, faith is defined as love (32). The document acknowledges (p. 22) that it is still the Roman Catholic position that while concupiscence remains in believers, 
side, soon after the statement was released, the Vatican followed up with disclaimers and even corrections of the Declaration, noting that it does not have any binding status. ${ }^{17}$

None of this means that the ecumenical project has reached an impasse. On the contrary, the honest recognition of remaining differences is the starting point for genuine dialogue. Ironically, at the very time that some evangelicals are attracted to Rome and notable evangelical scholars challenge the reformers' view, many of the best Roman Catholic New Testament scholars point out that the Reformers were right in their fundamental understanding of justification in the Bible as being declared right as opposed to being made right. ${ }^{18}$

Yet these differences seem irrelevant when one considers that Protestants today default to the same religion of the human heart. On the five-hundredth anniversary of the Reformation, Pew Research conducted a poll, leading to the conclusion that the Reformation is basically irrelevant today. A majority of U.S. Protestants (52\%) say both good deeds and faith in God are needed to get into heaven, a historically Catholic position. U.S. Protestants also are split on sola scriptura: again, a slight majority (52\%) say that Scripture is not the sole norm for faith and practice. Just $30 \%$ of all U.S. Protestants affirm both sola fide and sola scriptura. Only $44 \%$ of US evangelicals affirm both.

In line with previous surveys showing that Jews and Mormons knew better what Christians believed than professing Christians, the study found that only $65 \%$ of Protestants in America correctly identify the Reformation as the event in which a split occurred between Roman Catholics and Protestants. And the same number correctly identify Martin Luther as the person who sparked the Reformation. Only 23\% know that Protestants traditionally teach that salvation comes through faith alone and 45\% erroneously thought that both Protestants and Catholics teach that doctrine. For Protestants in western Europe, "Salvation comes through faith alone"

\footnotetext{
it is not properly called sin (hence, the denial of "simultaneously justified and sinful"). Further, "When Catholics affirm the 'meritorious' character of good works, they wish to say that, according to the biblical witness, a reward in heaven is promised to these works" (25). Whatever is said further to qualify this, nothing of traditional Tridentine theology has been changed. Thus, "The teaching of the Lutheran churches presented in this Declaration does not fall under the condemnations of the Council of Trent" (26) only because they are not the teachings that Trent condemned. In other words, the LWF essentially adopted the Roman Catholic position on these traditional differences. This is not to say that there are no impressive points of agreement in which to rejoice, but the Declaration takes the classic Roman Catholic side on the points that have been church-dividing.

17 See http://www.vatican.va/roman_curia/pontifical_councils/chrstuni/documents/rc_pc_chrstuni_ doc_01081998_off-answer-catholic_en.html. Retrieved August 14, 2017.

18 Joseph A. Fitzmeyer, Raymond Brown, among many other Roman Catholic exegetes agree that justification is a judicial verdict rather than a process of sanctification.
} 
is a minority view. In Sweden, among those who say that religion is "very" important in their lives, only $31 \%$ believe in sola fide. Although the Dutch have the highest church attendance in Europe (43\%), $48 \%$ of adults identify as atheists, agnostic or "nothing in particular."19

Evangelicalism has always been a mixed bag, but it always had a fair number of informed leaders who were rooted in Reformation traditions. I have always appreciated the courageous labors for the gospel by the pioneers of the modern missionary movement. Most of these leaders in fact were energized by Calvinistic and Lutheran confessional convictions. However, pietism and revivalism became carriers of an anti-Reformation bias that undermined the initial foundations of the movement, while professors in their seminaries began to sell their souls to the highest bidder for academic prestige and social respectability. In deference to a thoroughly ethical system, Albrecht Ritschl expunged from Christianity everything that presupposed any notion of objective guilt and divine wrath or justice needing to be satisfied. Thus, much of modern theology has followed Kant in concluding with Dorothee Sölle that the notion of Christ's righteousness being imputed to sinners qua sinners "destroys the ethical core of personality, namely, responsibility." ${ }^{20}$ This Enlightenment-liberal view of the self was assumed in the salons of Berlin and Paris that touched Jefferson, Franklin, Adams and others influenced by the French Revolution, as well as Transcendentalists like Emerson. In many ways, it was the consummation of the radical Anabaptist vision of the "Age of the Spirit" in which every individual knows God within, dispensing with every external authority and ministry.

However, a very similar "enlightenment" occurred on the American frontier with the self-confident autonomy of the "inner light" joined with a manipulative conversionism based on self-regeneration and the transformation of society. The broad river of modern evangelicalism is fed not only by Reformation streams but by the heritage of Anabaptist enthusiasm and Arminian, if not Semi-Pelagian, revivalism. Ironically, Charles G. Finney (1792-1875) parroted in his own pretentious way the doctrines of Kant but with an "evangelical" fervor that "got results," exactly the moral transformations Kant encouraged.

How can evangelicals celebrate the legacy of figures like Charles Finney while castigating the errors of Rome when the former's theology is far more

\footnotetext{
19 http://www.pewforum.org/2017/08/31/after-500-years-reformation-era-divisions-have-lost-muchof-their-potency/

20 Dorothee Sölle, Christ the Representative: An Essay in Theology after the 'Death of God' (London: SCM Press, 1967), 78-79.
} 
Pelagian than anything that was taught at the Council of Trent? Rejecting the doctrines of Christ's substitutionary atonement as contrary to reason and morality, he called the doctrine of justification by Christ's imputed righteousness "another gospel." Referring to the Westminster Confession's statement on justification, Finney declared, "If this is not antinomianism, I know not what is." Justification by Christ's imputed righteousness is not only "absurd," but undermines all motivation for personal and social holiness. In fact, "full present obedience is a condition of justification." No one can be justified "while sin, any degree of sin, remains in him." The teaching that believers are "simultaneously justified and sinful," he judges, "has slain more souls, I fear, than all the universalism that ever cursed the world." "Representing the atonement as the ground of the sinner's justification has been a sad occasion of stumbling to many." ${ }^{21}$ Nevertheless, the region of Finney's repeated revivals became known as the "burned-over district," as the enthusiasm waned and the erstwhile "born-agains" became mediums, psychics and atheists. $^{22}$

Is there not some connection between such enthusiasm and the "spiritual but not religious" trend in American society? If we could save ourselves through "new measures" (such as the altar call and other appeals to emotion and marketing techniques), we could save society — and the world - through moral transformation. There were (and are) liberal and conservative blueprints, but the same enthusiastic program of works-righteousness. As Finney's nemesis John Williamson Nevin pointed out, "the system of the catechism" with its emphasis on a sacramental education from cradle to grave was being totally undermined by "the system of the bench" (i.e., the altar call), where the ordained means of grace were supplanted by celebrity evangelists.

The following verdict might strike one as yet an exaggerated Calvinist screed: "The gospel preached and the doctrine of salvation taught in most evangelical pulpits and lecterns and believed in most evangelical pews is not classical Arminianism but semi-Pelagianism if not outright Pelagianism." ${ }^{23}$ However, this is the judgment of my friend and Arminian Baptist theologian, Roger Olson. Sociologist Christian Smith has documented that the working

21 All references from Charles G. Finney, Systematic Theology (Oberlin: J. M. Fitch, 1846; repr., Minneapolis: Bethany, 1976), 46, 57, 321-22.

22 Whitney Cross, The Burned-Over District: Social and Intellectual History of Western New York, 18001850 (Ithaca, NY: Cornell University Press, 1982).

23 Roger Olson, Arminian Theology: Myths and Realities (Downers Grove, IL: IVP, 2009), 30. He has reiterated more recently, "I have agreed with my Calvinist friends (like Mike Horton) that American Christianity is by-and-large Semi-Pelagian" (https://www.patheos.com/blogs/rogereolson/2011/02/ american-christianity-and-semi-pelagianism/). 
religion of most Americans today is "moralistic, therapeutic deism." ${ }^{24}$ As I noted above, Luther's teachers taught the theology that "God will not deny his grace to those who do what lies within them." We may be reminded of Benjamin Franklin's aphorism, "God helps those who help themselves," which, according to one survey, 75 percent of professing Christians endorsed and a majority thought was a biblical quotation. ${ }^{25}$

The justification of the ungodly has never been an essential doctrine in American evangelicalism. The central emphasis is conversion - the transformation of individuals from sinner to saint and of sinful societies into virtuous ones. Müntzer, not Luther, is the leading light of Protestantism in the United States. For the most part, doctrine gets in the way, which is why even evangelical theologians are often found re-inventing doctrines we share with Roman Catholicism and Orthodoxy, such as the Trinity. American Protestantism has been obsessed with defining itself against Rome, to the point of embracing an Anabaptist fanaticism that downplays even the formal ministry of Word and sacrament. This nineteenth and early twentieth-century fear of "papalism" had more to do with politics and cultural hegemony of WASP (White-Anglo-Saxon-Protestant) culture than of a concern to defend the chief article of the gospel.

A "Plan of Union" for American Protestantism was put forward in 1920, based on an "evangelical creed." Princeton theologian B. B. Warfield observed that the new confession being proposed "contains nothing which is not believed by Evangelicals," and yet "...nothing which is not believed ...by the adherents of the Church of Rome, for example." He noted, "There is nothing about justification by faith in this creed." But then again, he observed, there is nothing in the statement about the Trinity, the deity of Christ and the Holy Spirit, the atonement, or sin and grace. ${ }^{26}$ "Is this the kind of creed which twentieth-century Presbyterianism will find sufficient as a basis for co-operation in evangelistic activities? Then it can get along in its evangelistic activities without the gospel. For it is precisely the gospel that this creed neglects altogether." "“Fellowship is a good word," Warfield concludes, "and a great duty. But our fellowship, according to Paul, must be in 'the furtherance of the gospel."' 27

\footnotetext{
24 Christian Smith and Melinda Lundquist Denton, 2005 book Soul Searching: The Religious and Spiritual Lives of American Teenagers (New York: Oxford University Press, 2005).

25 Barna Research Online, "American Bible Knowledge Is in the Ballpark, but Often off Base" (July 12, 2000) at Barna, George, and Mark Hatch. 2001. Boiling Point: It Only Takes One Degree. Ventura, CA: Regal.

26 B. B. Warfield, "In Behalf of Evangelical Religion," in Selected Shorter Writings of Benjamin B. Warfield-I, ed. John E. Meeter (Nutley: Presbyterian and Reformed, 1970), 386

27 B. B. Warfield, "In Behalf of Evangelical Religion," 387
} 
In Warfield's day, evangelical union meant the uniting of what then constituted the majority of mainline Protestantism in America. In his day, that meant what we call evangelicalism today. Yet even the National Association of Evangelicals is united today by a statement of faith that affirms nothing that is distinctively evangelical. Although there are two points on the necessity of the Holy Spirit's work in regeneration and sanctification (affirmed also by Roman Catholic and Orthodox traditions), no mention is made of justification. ${ }^{28}$ Even where it agrees with the catholic consensus that churches of the Reformation affirm, it is superficial and inadequate in comparison with the ecumenical creeds. Paradoxically, confessional and Lutheran and Reformed traditions are more interested than Protestants (evangelical as well as liberal) in being Catholic (in the ecumenical, not Roman, sense) while being more alert to any threat to central Reformation emphases. At the end of his American tour - after which he would return to be hanged in a Nazi prison, Dietrich Bonhoeffer described the nation as "Protestantism without the Reformation." ${ }^{29}$

Even today, theological liberals in the US follow Finney instead of Luther and Calvin. Moral, social and political action, not the proclamation of Christ's alien righteousness, is the church's mission. Yet the same emphasis is found on the so-called Christian Right, with Müntzer-like insurrectionists storming the U. S. Capitol carrying crosses and Bible verses taken out of context. Apart from the specific policy-prescriptions, liberals and conservatives in the U.S. share the common legacy of "Protestantism without the Reformation."

So now here we are, after five centuries. Is the Reformation over? Clearly, Rome has not moved an inch toward the gospel. Instead, both Rome and Protestantism have moved further away from it in the direction of Semi-Pelagian if not outright Pelagian confidence in humanity to save itself. A recent article in The Atlantic bears the headline, "The Evangelical Church is Breaking Apart." "For many Christians, their politics has become more of an identity marker than their faith." The author, Peter Wehner, quotes a Presbyterian pastor: "We have forgotten the cross." ${ }^{30}$

\section{Conclusion}

I have spent a lot of space focusing on my own context of American

28 https://www.nae.net/statement-of-faith/ Retrieved 2 June, 2016.

29 Dietrich Bonhoeffer, "Protestantism without the Reformation," in No Rusty Swords: Letters, lectures and Notes, 1928-1936, ed. Edwin H. Robertson, trans. Edwin H. Robertson and John Bowden (London: Collins, 1965), 82-118.

30 Peter Wehner, "The Evangelical Church is Breaking Apart," The Atlantic, Oct 242021. 
evangelicalism. That is because it's where I come from. It is a source of great encouragement in many ways, but also of great disappointment. God has included American missions in his mighty work. Yet in its passion to get the gospel out it has often failed to get the gospel right. I offer this story as a cautionary tale to my brothers and sisters in the majority world that has been influenced by the good and the bad of our form of Christianity.

So is the Reformation over? It all depends. Anyone parent of teenagers today knows that "justification" is more existentially real than ever. Younger generations especially find their identity in social media, where their "likes" and "followers" become a measure of their worth. It is not God's verdict but that of their peers that condemns or justifies. According to the CDC, 1.38 million Americans attempted suicide in 2019 and 50,000 were successful. In addition, 841,000 died of drug overdose. ${ }^{31}$ It's time to challenge the "theology of glory," as Luther called it, with the "theology of the cross."

At least Rome and the Reformers shared a world in which heaven and hell hung in the balance. Christ would arraign all before his bar. This common horizon made the Reformation debates relevant.

Today, however, people still have the same nagging sense of guilt, but don't know where it comes from, much less what can be done about it. We still find ways to "suppress the truth in unrighteousness" - even to the point of idolatry, or for that matter, atheism, but is it not at bottom an effort to evade an objective and therefore condemning evaluation of our life? Friedrich Nietzsche came closer than many preachers today with his character, "the Ugliest Man" in "Thus Spake Zarathustra." The God who beholds all, "'men's depths and dregs,"' had even "'crept into my dirtiest corners,"' said Nietzche's ugliest man. "'On such a witness I would have revenge-or not live myself. The God who beheld everything, and also man: that God had to die! Man cannot endure it that such a witness should live."'32

But the price of this evasion is steep, even if only in existential terms. "Man is nothing else but that which he makes of himself," Sartre asserted, and bears "the entire responsibility for his existence squarely upon his own shoulders." ${ }^{\prime 3}$ That is an astonishing doctrine. Is it any wonder that we would rather be accountable for this burden to ourselves rather than to an external authority who has the power-and the right-to judge us? Is not such secularized Pelagianism (as if the heresy itself is not already secularized

\footnotetext{
31 https://www.cdc.gov/drugoverdose/deaths/index.html

32 Friedrich Nietzsche, "Thus Spake Zarathustra" in The Philosophy of Nietzsche, trans. Thomas Common (New York: Random House, nd), 207.

33 Walter Kaufman, Existentialism from Dostoevsky to Sartre (New York: Penguin Random House, 1975), 291.
} 
enough) the incubator of so many of our anxieties?

Robert J. Lifton, a psychiatrist and pioneer in brain research, observes that the source of many neuroses in society today is a nagging sense of guilt without knowing its source. ${ }^{34}$ The anxiety is "a vague but persistent kind of self-condemnation related to the symbolic disharmonies I have described, a sense of having no outlet for his loyalties and no symbolic structure for his achievements." I interpret this theologically as suggesting that there is no external law to measure oneself by or external gospel through which one becomes re-scripted "in Christ." "Rather than being a feeling of evil or sinfulness," he says, "it takes the form of a nagging sense of unworthiness all the more troublesome for its lack of clear origin." 35

Preachers who want to appeal to the felt needs of people today assume that they already know what they need. Our job is simply to show them how Jesus is the answer to their questions. But our job is to show them that their felt needs aren't their real needs. Deep down, they know that superficial diagnoses will not suffice. We don't even know the right questions until the law arraigns us before God's bar. No longer pretending, giving excuses, blaming others, we are called to account.

It may be that the justification of the ungodly is not on everyone's radar. But when has the question, "How can I be saved?" ever been a common question of the average person? Regardless of whether this was an urgent question of Jews of the Second Temple period (and it was), it was evidently provoked repeatedly by the preaching of Jesus and the apostles as they exposed human guilt, corruption and death and pointed to Golgotha and the empty tomb as its solution. Jesus upbraided the religious specialists for refusing him because they "trusted in themselves that they were righteous" and, consequently, missing the whole point of their own scriptures.

Evidently, the Apostle Paul did not find a ready audience for his message either, reporting that most Jews found it "a stumbling block" and most Greeks found it simply "foolishness." The greatest threat to the gospel came not from external forces but from within the churches themselves, as Paul's stern warning to the Galatians made clear. Yet it is precisely in its foolishness that the gospel is "the power of God unto salvation for all who believe." Let us never lose our confidence in that gospel. Let us never take it for granted, assuming it as something we already know. We are no better than anyone else, but are always those who can only echo Luther's dying words, “We

34 Robert J. Lifton, The Protean Self: Human Resilience in an Age of Fragmentation (Chicago: University of Chicago Press, 1999), 101.

35 Robert J. Lifton, "The Protean Self" in The Truth About the Truth: De-confusing and Re-constructing the Postmodern World, ed. Walter Truett Anderson (New York: Putnam, 1995), 133. 
are all beggars. That is most certainly true."

\section{References}

Bainton, Roland. Here I Stand: A Life of Martin Luther. Nashville: Abingdon Press, 1950.

Barna, George, and Mark Hatch. 2001. Boiling Point: It Only Takes One Degree. Ventura, CA: Regal.

Bonhoeffer, Dietrich "Protestantism without the Reformation," in No Rusty Swords: Letters, lectures and Notes, 1928-1936, ed. Edwin H. Robertson, trans. Edwin H. Robertson and John Bowden. London: Collins, 1965.

Brown, Stephen "Reformation celebrations will be ecumenical and international, says German Protestant leader," https://www.oikoumene. org/en/press-centre/news/reformation-celebrations-will-be-ecumenical-and-international-says-german-protestant-leader, retrieved 2 July, 2016.

Calvin, "Reply by John Calvin to Cardinal Sadoleto's Letter," in Selected Works of John Calvin: Tracts and Letters, ed. Henry Beveridge and Jules Bonnet, 7 vols. (Grand Rapids: Baker, 1983), 1:36.

Clark, R. S. "Iustitia Imputata Christi: Alien or Proper to Luther's Doctrine of Justification?", Concordia Theological Quarterly 70:3/4 (July/Oct 2006): 269-310.

Cross, Whitney. The Burned-Over District: Social and Intellectual History of Western New York, 1800-1850. Ithaca, NY: Cornell University Press, 1982.

Finney, Charles G. Systematic Theology. Oberlin: J. M. Fitch, 1846; repr., Minneapolis: Bethany, 1976.

Hendrix, Scott. Martin Luther: Visionary Reformer. New Haven: Yale University Press, 2015.

Jüngel, Eberhard. Justification: The Heart of the Christian Faith, trans. Jeffrey F. Cayzer; $2^{\text {nd }}$ ed. London: Bloomsbury T\&T Clark, 2014.

Kaufman, Walter. Existentialism from Dostoevsky to Sartre. New York: Penguin Random House, 1975.

Lifton, Robert J. "The Protean Self" in The Truth About the Truth: De-confusing and Re-constructing the Postmodern World, ed. Walter Truett Anderson. New York: Putnam, 1995.

. The Protean Self: Human Resilience in an Age of Fragmentation. Chicago: University of Chicago Press, 1999.

Luther, "Smalcald Articles" III.4-15 at http://bookofconcord.org/smalcald. php.

Luther, Werke, Erlangen ed., 28, pp. 219, 260.

Luther, "Smalcald Articles," in Triglot Concordia: The Symbolical Books of the 
Evangelical Lutheran Church (St. Louis: Concordia, 1921), 3.8.

Nietzsche, Friedrich. "Thus Spake Zarathustra" in The Philosophy of Nietzsche, trans. Thomas Common. New York: Random House.

Olson, Roger. Arminian Theology: Myths and Realities. Downers Grove: IVP, 2009.

Smith, Christian and Melinda Lundquist Denton. Soul Searching: The Religious and Spiritual Lives of American Teenagers. New York: Oxford University Press, 2005.

Sölle, Dorothee. Christ the Representative: An Essay in Theology after the 'Death of God'. London: SCM Press, 1967.

Warfield, B. B. "In Behalf of Evangelical Religion," in Selected Shorter Writings of Benjamin B. Warfield -I, ed. John E. Meeter. Nutley: Presbyterian and Reformed, 1970.

Wehner, Peter. "The Evangelical Church is Breaking Apart," The Atlantic, Oct 242021.

The Catechism of the Catholic Church. New York: USCCB, 1995.

Lutheran World Federation and the Roman Catholic Church, Joint Declaration on the Doctrine of Justification. Grand Rapids: Eerdmans, 2000.

http://www.vatican.va/roman_curia/pontifical_councils/chrstuni/documents/rc_pc_chrstuni_doc_01081998_off-answer-catholic_en.html. Retrieved August 14, 2017.

http://www.pewforum.org/2017/08/31/after-500-years-reformation-era-divisions-have-lost-much-of-their-potency/

https://www.patheos.com/blogs/rogereolson/2011/02/american-christianity -and-semi-pelagianism/

https://www.nae.net/statement-of-faith/ Retrieved 2 June, 2016.

https://www.cdc.gov/drugoverdose/deaths/index.html 